\title{
The determinants of grain storage technology adoption in Sierra Leone
}

\author{
Alhaji Mohamed Hamza Conteh ${ }^{1}$ \\ Xiangbin $\mathrm{Yan}^{2}$ \\ Juana Paul Moiwo ${ }^{3}$ \\ ${ }^{1}$ Njala University \\ Department of Mathematics and Statistics \\ Njala \\ Sierra Leone \\ $<$ hadjmannc90@yahoo.com> \\ 2 Harbin Institute of Technology \\ School of Management \\ Department of Management Science and \\ Engineering \\ 150001 Harbin \\ China \\ <xbyan@hit.edu.cn> \\ ${ }^{3}$ Njala University \\ School of Technology \\ Njala \\ Sierra Leone \\ <jupamo2001@yahoo.com>
}

\begin{abstract}
In Sierra Leone, there is renewed concern about post-harvest losses which account for $20-30 \%$ loss of farm produce. The lack of adequate storage facilities also affects produce quality, reducing produce market value with negative implications for various parts of the value chain (consumers, processors, etc.) requiring high quality raw materials. This study uses the Logistic Regression Model to determine the factors that influence the adoption of Grain Storage Technologies (GSTs) promoted by Sierra Leone Agricultural Research Institute (SLARI) in Sierra Leone. The study shows that education, household size and cultivated grain type are positively related to GST adoption, while farming and farmland acquisition modes are negatively related to their adoption. Interestingly, access to credit and extension services have little influence on the adoption of GST. Credits, like extension services, are haphazard and random with high interest rates and political connotations that farmers generally detest. As rural farmers are largely poor, GSTs are generally viewed as additional expenditures. It is appropriate that SLARI, government and other stakeholders refocus efforts on collective/community post-harvest storage systems such as farmer/ community associations and co-operations. Facilitating efficient post-harvest storage systems in rural/farming communities benefits not only farmers in terms of increased income, but also hunger-stricken populations across Sub-Saharan Africa in terms of food security.
\end{abstract}

Key words: grain storage technology; logistic regression model; post-harvest loss; Sierra Leone.

Subjects: economy and rural development; technology, crops, transport; processing, marketing.

\section{Résumé \\ Les déterminants de l'adoption de la technologie de stockage des céréales en Sierra Leone}

En Sierra Leone, on observe un regain d'inquiétude concernant les pertes post-récolte, qui représentent 20 à $30 \%$ des produits de l'exploitation. De plus, le manque d'équipements de stockage adéquats affecte la qualité des produits, réduit leur valeur marchande, avec des implications négatives sur les différents maillons de la chaîne de valeur (consommateurs, transformateurs, etc.) qui ont besoin d'une matière première de bonne qualité. La présente étude utilise le modèle de régression logistique, afin de déterminer les facteurs influençant l'adoption des technologies de stockage de céréales (GST) développées par l'Institut de recherche agricole de Sierra Leone (SLARI). L'étude montre que l'éducation, la taille du ménage et le type de céréale cultivée sont corrélés positivement avec l'adoption des GST. Par contre, la pratique agricole et le mode d'acquisition des terres sont corrélés négativement à l'adoption des GST. L'accès aux services de crédit et de vulgarisation influence peu l'adoption des GST. Le crédit, comme les services de vulgarisation, est généralement incertain, aléatoire, présente des taux d'intérêts élevés et une connotation politique dont les agriculteurs se méfient. En outre, la plupart des agriculteurs ont des ressources limitées et l'adoption des GST est perçue comme une dépense supplémentaire. Il paraît utile que le SLARI, le gouvernement et les
Reprints: A.M.H. Conteh doi: 10.1684/agr.2015.0733
To cite this article: Conteh AMH, Yan X, Moiwo JP, 2015. The determinants of grain storage technology adoption in Sierra Leone. Cah Agric 24: 47-55. doi : 10.1684/agr.2015.0733 
W

ith an increasing global population and irregular food prices, there is renewed interest in food security (Francis et al., 2003). Food security is the physical, social and economic access to sufficient, safe and nutritious food which meets the dietary needs of a healthy and active life (PinstrupAndersen, 2009). Food security is achieved not only by increasing food production, but also by reducing losses and wastes along the food supply chain. Food loss is the avoidable deduction of the amount of food along the supply chain, from cultivation to end consumption (Parfitt et al., 2010). As over 33\% (1.3 billion ton) of food produced globally is lost/wasted every year (WB/FAO, 2011), food security remains a challenge for both developed and developing countries (USDA, 2000).

The estimated losses of selected grains at different post-harvest phases in Africa are $4 \%$ during harvesting, 4\% during drying, 3\% during shelling/ threshing, 3\% during winnowing, 3\% during transportation and 6\% during storage: totaling 22\% (APHLIS, 2011; WB/FAO, 2011). Of the various stages (pre-harvest, at-harvest and post-harvest) of the food supply chain, the post-harvest stage shows the highest loss (Heritz, 2004; FAO, 2011). Postharvest loss, however, remains a secondary priority. Records concerning it are highly variable and/or poorly documented (Rembold et al., 2011). In percentage terms, post-harvest loss in industrialized countries (40\%) is as high as in developing countries. However, whereas it occurs mainly during the retailer/consumer phase in the developed world, post-harvest

autres parties prenantes recentrent leurs efforts sur des systèmes collectifs de stockage post-récolte à travers, par exemple, les associations paysannes ou les coopératives. Promouvoir des systèmes collectifs efficaces de stockage post-récolte profite non seulement aux agriculteurs en termes d'augmentation des revenus, mais aussi à la frange de population frappée par la faim en Afrique subsaharienne.

Mots clés : modèle de régression logistique ; perte post-récolte ; Sierra Leone ; technologie de stockage de grains.

Thèmes : économie et développement rural ; technologie, récolte et transport ; transformation, commercialisation.

loss occurs largely during the storage phase in developing countries. Postharvest loss is therefore mainly a consumer behavior factor in developed countries while it is an infrastructural factor in developing countries due largely to financial, managerial and technical limitations. Of the $460 \mathrm{~kg} / \mathrm{yr}$ per capita food production in Sub-Saharan Africa, $33 \%$ is lost to post-harvest loss (WB/ FAO, 2011). Annually, post-harvest loss of cereal grains alone is valued at USD 1.6 billion for East/Southern Africa and at USD 4 billion for SubSaharan Africa (WB/FAO, 2011). This exceeds the value of total food aid given to Sub-Saharan Africa in the 1998-2008 period, equals the value of cereal imports from 2000-2007, and represents enough for annual calorie requirements of 48 million people (APHLIS, 2011). This vividly explains the negative implications of postharvest loss for not only the men and women in the food supply chain, but for food security as well. Postharvest loss represents a waste of scarce resources (land, water and agro-inputs) as the produced food is never consumed (Parfitt et al., 2010). Cereals constitute the world's largest staple food and account for some 55\% of Africa's food basket (Vallier et al., 2009). For every $1 \%$ rise in global food prices, expenditure on food drops by $0.75 \%$ in developing countries (FAO, 2011). Reducing post-harvest loss not only increases food availability, farmer income and consumer savings, but also reduces agro-related greenhouse gas emissions (APHLIS, 2011). Investment in post-harvest storage is costeffective and environmentally efficient, with the potential to reverse current high food prices and food insecurity (Tester \& Langridge, 2010). Assessments of the range of complexities regarding decisions on the adoption of new technologies, farmer/ consumer benefits and food security are generally inadequate (Kleijnen et al., 2004). Adoption of technology is the behavioral decision and orientation towards desired goals (Tan et al., 2009). Adoption is generally a slow process (Guha \& Leonard, 2002), rationalized through derived benefits (Basorun \& Fasakin, 2012) against various limitations (Chandola et al., 2011). Conventional storage facilities in Sierra Leone are temporary, and composed of sub-standard materials which expose grains to infestations (Odeyemi et al., 2010). In addition, storage in designed grain reserves, barrier stocks and farmhouses provide over $80 \%$ of the local grain supply. Over $90 \%$ of the population consumes grains as staple food, necessitating the promotion of efficient grain storage technologies to ensure food security (Maconachie \& Hilson, 2011).

The objective of this study is to determine the factors which influence the adoption of grain storage technologies promoted by SLARI (Sierra Leone Agricultural Research Institute) in Sierra Leone. The study analyzes key farmer demographic, agronomic and financial factors in relation to SLARIpromoted grain storage technologies using the Logistic Regression Model. The overall goal is to increase food supply without necessarily expanding the areas under farmland. This effort will have beneficial effects on the millions of resource-poor and underfed population of Sierra Leone and elsewhere in the developing world. 


\section{Methodology}

\section{The study area}

The study area covers suburban Bo, Kenema, Makeni and Freetown, which are respectively the provincial headquarter towns of the Southern, Eastern and Northern Provinces and the capital city of Sierra Leone (figure 1). The predominantly smallscale farmers in the study area are engaged mainly in rice, maize, millet, yam, bean, cassava and vegetable production. The study mainly targets farmers engaged in grain crop production. The respondents (a total of 210) were randomly selected from 30 farming communities in the study area.

\section{Data collection}

The data were collected from a total of 30 farming communities - 19 communities from the three provinces and 11 from the Western Area region. In each of the communities, seven grain producers were selected using the simple random sampling technique. In all, a total of 210 grain producers were interviewed in the study. The main criteria for inclusion in the random sampling for interview were: (i) active engagement in farming activities over the last 10 years to the study; (ii) a minimum grain production of 3 ton $/ \mathrm{yr}$; and (ii) trial and/or full adoption of one or more SLARI-promoted grain storage technologies. The questionnaires designed for the interviews were translated into the local dialects of the respective farming communities to avoid ambiguity. The farmer-tailored questionnaires solicit information on socio-economic and agronomic factors affecting adoption decisions on post-harvest storage technologies. The question-

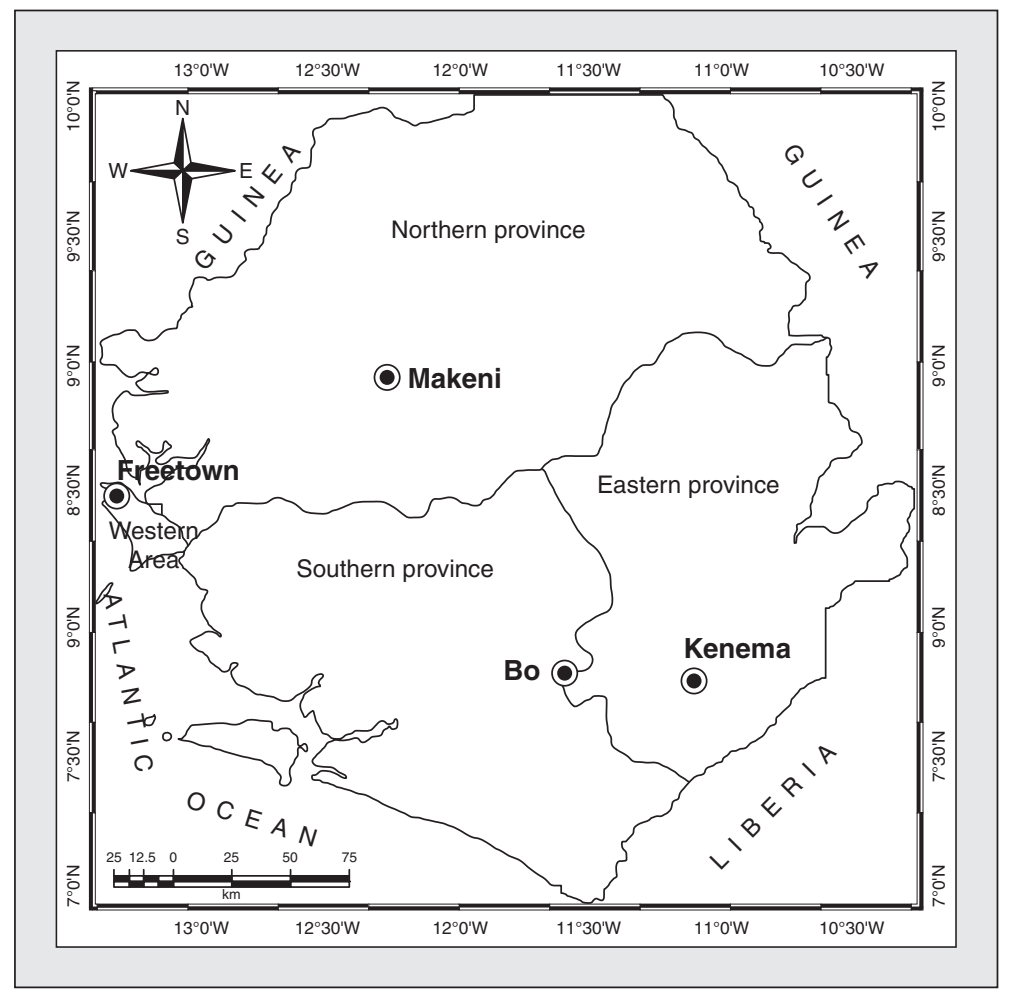

Figure 1. A location map of Sierra Leone depicting the provincial divisions and the Western Area in solid lines along with the selected study areas in eyed-dots.

Figure 1. Carte de Sierra Leone présentant les différentes provinces et la Région occidentale. Les régions d'étude choisies sont indiquées par des points.

naires cover such areas as awareness, ease of use and limitations of SLARIpromoted grain storage technologies in the region.

\section{SLARI-promoted grain storage technology}

Grain storage technologies promoted by SLARI in the study area include crib storage, granary storage, polypropylene-lined sack storage and hermetic storage. Details about the applicabilities of the technologies in terms of agro-geographic location, labor requirements, procurement/construction costs, management/maintenance challenges and grain preservation effectiveness are documented at http:// www.erails.net/SL/slari/slari/Home/.

Crib storage is used mainly to store maize cobs under well aerated conditions. In crib storage, natural air circulation and drying preserve and protect harvested maize grains. To prevent pest infestation during crib storage, maize grains are treated with actellic dust or other agro-chemicals (Goldman, 1991). This technique is common in the northern and southern regions of Sierra Leone.

In granary storage shelled/unshelled grains are put into sacks or jute-bags and then onto pallets in stores. This method is used for storing large quantities of grains. The stored grain sacks/bags are sufficiently spaced to enhance monitoring and treatment (often with actellic dust) of the grains for pest infestations.

Polypropylene-lined sack storage is the use of bulk-bags (usually made of woven fabric, such as polypropylene) to hold large/weighty quantities of grains, usually in excess of $1,000 \mathrm{~kg}$ (Navin, 2001). This technique is effective against pest infestation and is especially popular among small-scale grain farmers in Sierra Leone.

Hermetic storage maintains reasonable moisture content at a stable relative humidity (Ellis, 2007). It involves storage of sufficient quantities of grain in sealed containers or jugs, usually for use by farming households. Grains kept in air-tight jugs are sufficiently dried to prevent mould/fungi infection. Containers such as polythene bags, oiled drums and plastic drums can effectively serve this purpose. 


\section{Statistical analysis}

The analytical method used in this study includes descriptive (standard deviation, frequency, mean and percentage) and inferential (logistic regression) statistics. The analysis explains the associations among the dependent (outcome) and independent (explanatory) variables considered in the study. It also explains the key adoption factors of grain storage technologies promoted by SLARI in Sierra Leone.

Logistic regression is suitable for treating processes with dichotomous criteria (Tourenq et al., 2001). This regression method neither produces probabilities that lie below zero or above one nor imposes restrictive normality assumptions on the predictors. It is a generalized linear model that is specifically a type of binomial regression. Logistic regression transforms a limited $[0,1]$ into a full $[-\infty$. $+\infty$ ] range of probability, making the transformed values fit for linear functions (Howell, 2010).

A logistic regression is set about as a logistic function which, like probability, takes on values between 0 and 1 as:

$$
\begin{aligned}
\pi(x) & =\frac{e^{\left(\beta_{0}+\beta_{1} x\right)}}{e^{\left(\beta_{0}+\beta_{1} x\right)}+1} \\
& =\frac{1}{e^{-\left(\beta_{0}+\beta_{1} x\right)+1}}
\end{aligned}
$$

In the above equation, $\beta_{O^{+}} \beta_{1} x$ is the input and $\pi(x)$ the output (or the probability of being a case), with $\beta_{O}$ the intercept from the linear regression equation (the value of the criterion when the predictor is equal to zero) and $\beta_{1} x$ the regression coefficient multiplied by some value of the predictor $(x) . \pi$ is pie (with value of 22/7), and $e$ is the base exponential function (commonly taken as 2.71828). The logistic function takes as input any value from negative $(-\infty)$ to positive $(+\infty)$ infinity and confines output to between zero (0) and one (1).

The logit function $g(x)$ of a given predictor $x$ is expressed as:

$g(x)=\operatorname{In} \frac{\pi(x)}{1-\pi(x)}=\beta_{0}+\beta_{1} x$

where is the natural logarithm. The odds of an outcome being a case is then equivalent to the exponential function of the linear regression equation, expressed as:

$\frac{\pi(x)}{1-\pi(x)}=e^{\left(\beta_{0}+\beta_{1} x\right)}$

This presents the logit as a link function between the odds and the linear regression equation. Hence as the logit varies from $-\infty$ to $+\infty$, it provides an adequate criterion for conducting linear regression with the logit easily convertible into odds (Hosmer \& Lameshow, 2000).

In this study, grain storage technology adoption is used as dependent variables or outcomes $(Y)$, while farmer characteristics are treated as independent or explanatory variables $(x)$. From here, the general logistic regression model used is simplified as in (Condous et al., 2004):

$$
\begin{aligned}
Y_{i}= & \alpha+\beta_{1} x_{1, i}+\beta_{2} x_{2, i}+\beta_{3} x_{3, i} \\
& +\cdots+\beta_{n} x_{n, i}+\varepsilon
\end{aligned}
$$

where $Y_{i}$ is the adoption probability (outcome) of the ith dependent variable (grain storage technology), $\alpha$ is the regression constant, $x_{1, i}, x_{2, i}$, $x_{3, i},{ }^{\dot{s} \dot{s}} x_{n, i}$ the tested farmer characteristics for $Y_{i}$ ranging from the first $\left(x_{1, i}\right)$ to the nth $\left(x_{n, i}\right)$ variable, and $\varepsilon$ the error term.

As stated, the minimum farmer grain production capacity for participation in the interviews was 3 ton/yr. The investigated farmer demographic characteristics included age, sex, marital status, educational level and household size. Credit access, farmland acquisition mode, farming mode, farm size, extension service access, farming experience and cultivated grain types were also investigated. The main cultivated grain crops in the country include rice, maize, millet and sorghum, in that order of importance in terms of demand. Soya bean and broad bean are the most cultivated legume crops, also in that order of importance in terms of demand.

The Wald statistic is used to assess the contribution of each individual predictor in the above model. The Wald statistic, like t-test in linear regression, assesses the coefficient of significance. It is the ratio of the square of the regression coefficient $\left(\beta_{j}\right)$ to the square of the standard error $(S E)$ of the coefficient, expressed as (Menard, 2002):

$$
W_{j}=\frac{\beta_{j}^{2}}{S E_{\beta_{j}}^{2}}
$$

\section{Results}

\section{Farmer descriptive profile}

Table 1 shows that about $81 \%$ of the farmers are married and that the rest are single, divorced or widowed. Generally, rural farmers in developing countries rely on human labor for various farm operations. Rural farmers therefore marry at early ages and bring up children who later provide needed farm labor. Farmland size is generally related to available family labor, which in turn influences the need for storage technology (Deressa et al., 2009).

Table 1 also shows that some $85 \%$ of the respondent farmers are in the age group of 30-47 years, suggesting a young farmer population in the country. As noted in earlier studies (Alavalapati et al., 1995), young farmers more readily adopt new farming technologies. Another 84\% of the respondents are full-time farmers. In fact, Toenniessen et al. (2008) noted that a large proportion of the population of Sub-Saharan Africa resides in rural areas and relies on agriculture for a livelihood. Because of limited offfarm or white-collar jobs in Africa, a significant fraction of the population takes to rural livelihood with agriculture as the mainstay.

Analysis of land tenure systems suggests that some $71 \%$ of farmlands in Sierra Leone are inherited. To maximize output, young farmers with inherited family farmlands (in the mostly communal land tenure system) are more likely to try modern technologies (Tiamiyu et al., 2009). As most rural farmers are poor and lack collateral security, they are hardly considered credit worthy by loan institutions. Table 1 shows that some $72 \%$ of the respondents have no access to credit. Where capital is a key constraint to farming, access to 
Table 1. Descriptive statistics of the $\mathbf{2 1 0}$ respondent farmers regarding the factors that influence the adoption of grain storage technologies promoted by the Sierra Leone Agricultural Research Institute (SLARI) in Sierra Leone.

Tableau 1. Statistiques descriptives des 210 agriculteurs interrogés, concernant les facteurs influençant l'adoption de technologies de stockage des céréales promues par I'Institut de recherche agricole (SLARI) en Sierra Leone.

\begin{tabular}{|c|c|c|c|c|}
\hline Grain storage adoption factor & & PRF (\%) & Mean & SD \\
\hline \multirow{5}{*}{ Age (yr) } & $<35$ & 25.0 & \multirow{5}{*}{42.8} & \multirow{5}{*}{ \pm 7.2} \\
\hline & $36-41$ & 06.9 & & \\
\hline & $41-47$ & 52.8 & & \\
\hline & $48-53$ & 03.1 & & \\
\hline & $>53$ & 11.8 & & \\
\hline \multirow{4}{*}{ Marital status } & Single & 06.9 & \multirow{4}{*}{25.0} & \multirow{4}{*}{ \pm 27.8} \\
\hline & Married & 80.6 & & \\
\hline & Divorced & 04.9 & & \\
\hline & Widowed & 07.6 & & \\
\hline \multirow{5}{*}{ Educational level } & No education & 21.5 & \multirow{5}{*}{19.98} & \multirow{5}{*}{ \pm 11.3} \\
\hline & Primary education & 27.1 & & \\
\hline & Secondary education & 34.0 & & \\
\hline & Adult education & 07.6 & & \\
\hline & Tertiary education & 09.7 & & \\
\hline \multirow{2}{*}{ Farming mode } & Full-time & 84.0 & \multirow{2}{*}{50.0} & \multirow{2}{*}{ \pm 34.0} \\
\hline & Part-time & 16.0 & & \\
\hline \multirow{3}{*}{ Farm acquisition mode } & Inherited & 70.8 & \multirow{3}{*}{33.3} & \multirow{3}{*}{ \pm 25.0} \\
\hline & Leased & 12.5 & & \\
\hline & Purchased & 16.7 & & \\
\hline \multirow{2}{*}{ Credit access } & Access & 28.5 & \multirow{2}{*}{50.0} & \multirow{2}{*}{ \pm 21.5} \\
\hline & Non-access & 71.5 & & \\
\hline \multirow{2}{*}{ Extension service access } & Access & 26.4 & \multirow{2}{*}{50.0} & \multirow{2}{*}{ \pm 23.6} \\
\hline & Non-access & 73.6 & & \\
\hline
\end{tabular}

PRF denotes the percent of respondent farmers and SD is the standard deviation.

PRF désigne le pourcentage des agriculteurs interrogés et SD l'écart type.

credit could positively influence the adoption of agro-technology (Karki, 2004).

Only a small $26 \%$ of the farmers have access to extension services/agents. As most rural communities in SubSaharan Africa are poor (lacking even basic information tools such as radio or television sets), extension services/agents could provide critical information about new farming practices and technologies. In SubSaharan Africa, severe financial constraints limit the hiring of extension agents in the agricultural sector. This limits the frequency of farmers' contacts with extension agents, which in turn limits the quality of extension services and farmer awareness of agricultural technologies (Davis, 2008).

\section{Technology adoption}

Table 2 lists the Logistic Regression Model estimated values for the factors influencing farmers' decisions to adopt or abandon grain storage technologies promoted by SLARI in Sierra Leone. Overall, the model predicts some $88 \%$ of the variations in farmer behavior regarding technology adoption decisions. The estimated likelihood coefficient via a chi-square ratio is significant at 0.05 and at a chi-square value of 105.6.
The obtained Nagelkerke $R^{2}$ value suggests that the model accounts for over $69.6 \%$ of the variations among adopters and non-adopters of the SLARI-promoted grain storage technologies in the study area.

Based on the results, five of the tested variables significantly influence farmers' adoption of SLARI-promoted grain storage technologies in the region. These variables include farming mode, educational level, household size, land acquisition mode and cultivated grain type (highlighted grey in table 2). As the significance (denoted as "Sig." in table 2) of the above five variables is stronger than the tested value of 0.05 , these variables are the 
Table 2. Logistic regression model estimates of the factors that influence farmers' adoption of grain storage technologies promoted by the Sierra Leone Agricultural Research Institute (SLARI) in Sierra Leone.

Tableau 2. Estimation, par le modèle de régression logistique, des facteurs influençant l'adoption de technologies de stockage des céréales promues par I'Institut de recherche agricole (SLARI) en Sierra Leone.

\begin{tabular}{|c|c|c|c|c|c|}
\hline Variable & $\boldsymbol{\beta}$ & SE & Wald & Sig. & $\operatorname{Exp}(\beta)$ \\
\hline $\operatorname{Sex}(1)$ & 1.852 & 0.972 & 3.635 & 0.057 & 6.375 \\
\hline Age (1) & 0.158 & 0.137 & 1.325 & 0.250 & 1.171 \\
\hline MAS(1) & -0.102 & 1.409 & 0.005 & 0.943 & 0.903 \\
\hline MAS(2) & -2.636 & 1.530 & 2.970 & 0.085 & 0.072 \\
\hline $\operatorname{MAS}(3)$ & 0.302 & 0.975 & 0.096 & 0.757 & 1.353 \\
\hline FAM(1) & -1.835 & 0.857 & 4.584 & 0.032 & 0.160 \\
\hline EDL(1) & 1.895 & 1.506 & 1.585 & 0.208 & 6.655 \\
\hline EDL(2) & 1.675 & 1.092 & 2.351 & 0.125 & 5.338 \\
\hline EDL(3) & 3.054 & 1.183 & 6.667 & 0.010 & 7.192 \\
\hline EDL(4) & 5.902 & 1.555 & 8.399 & 0.000 & 9.796 \\
\hline FAS(1) & 0.007 & 0.150 & 0.002 & 0.962 & 1.007 \\
\hline $\mathrm{HHS}(1)$ & 0.960 & 0.361 & 7.071 & 0.008 & 2.612 \\
\hline $\mathrm{FAE}(1)$ & -0.162 & 0.896 & 0.003 & 0.857 & 0.851 \\
\hline LAM(1) & -2.384 & 1.032 & 5.340 & 0.021 & 0.092 \\
\hline LAM(2) & -1.206 & 1.110 & 1.287 & 0.257 & 0.284 \\
\hline CRA(1) & 0.702 & 0.970 & 0.524 & 0.469 & 2.019 \\
\hline $\mathrm{ESA}(1)$ & 0.192 & 0.860 & 0.050 & 0.823 & 1.212 \\
\hline CGT(1) & 1.567 & 0.316 & 9.590 & 0.000 & 4.794 \\
\hline CST & -7.112 & 4.678 & 6.864 & 0.001 & 0.000 \\
\hline
\end{tabular}

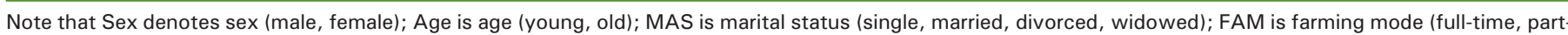

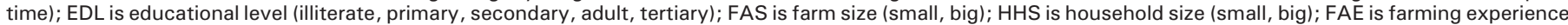

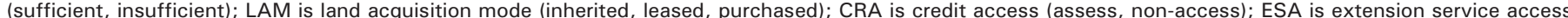

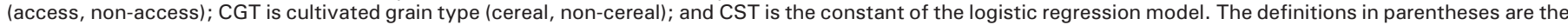
dummy variables associated with the independent (explanatory) variables.

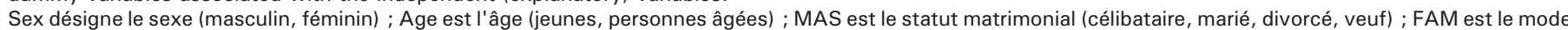

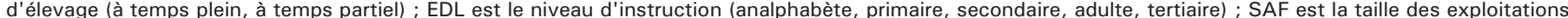

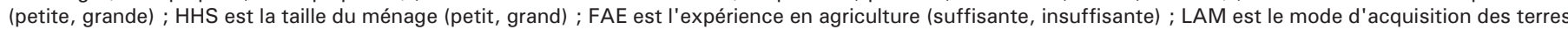

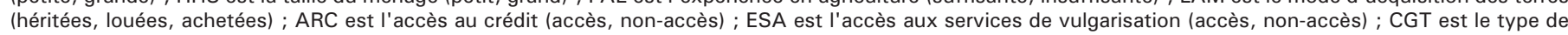

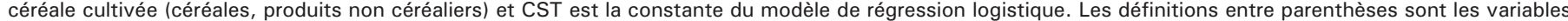
indicatrices associées aux variables indépendantes (explicatives).

focus of the discussions presented in subsequent sections of this paper.

\section{Discussion}

\section{Farming and technology adoption}

Farming mode (with part-time farming as the dummy variable) is nega- tively related to grain storage technology adoption (table 2). Nonfarming activities that are direct sources of quick cash normally compete with farming activities for household incomes (Ibekwe et al., 2010). Under such conditions, part-time farmers attach less value to less visible farm operations, such as proper grain storage. Generally, part-time farmers produce merely enough for household consumption. This set of farmers there- fore has little desire for long-term storage technologies that require additional adoption costs.

\section{Education and technology adoption}

Some $79 \%$ of the respondent farmers have some level of education. With the exception of the "no education or illiterate" variable, all the dummy 
variables of education are positively correlated with the farmer educational level. The positivity of the correlations strengthens with higher education level (table 2). This is in agreement with the findings of Lleras-Muney (2005), that farmers with higher education are more likely to adopt new agricultural technologies. Most of the respondent farmers have some sort of formal education, which positively influences decisions to adopt grain storage technologies promoted by SLARI in the study area. Education enhances the ability of farmers to understand and efficiently manage relatively complex agrarian technologies (Agwu et al., 2008). In addition, with good education, farmers can learn about agricultural technologies from sources (e.g., newspapers, farm radios, etc.) other than extension agents/services.

\section{Household size and technology adoption}

The Logistic Regression Model results show a positive correlation between household size and SLARI-promoted grain storage technology adoption in the study area. Wetengere (2010) noted that the tendency to adopt agrotechnologies increases with increasing size of the farming household. Neupane et al. (2002) also noted a similar trend, suggesting that large farming households are more likely to accept the SLARI-promoted grain storage technologies.

In fact in the study area, most of the larger farming households have large farm sizes. The main staple food in Sierra Leone is rice, followed by maize, millet and sorghum. The fact that they are labor intensive staples suggests that household size influences the amount of grains produced as farming is largely dependent on human labor. The higher the level of farm production, the greater the need for better and more efficient grain storage facilities for both later sales and internal consumption. Some of the promoted storage technologies (e.g., crib and hermetic storage) are as well labor intensive, requiring large family sizes in the predominantly human-labor-driven agrarian systems. Hence, the need for more food for internal consumption and for good market prices during off-season peri- ods drive farmers with large family sizes to adopt grain storage technologies.

\section{Farmland acquisition and technology adoption}

The mode of acquisition of farmland is negatively related to grain technology adoption in the study area. Studies on land tenure systems reveal that leasing and purchasing farmlands negatively influence the adoption of agro-technology (Soule et al., 2000). Other studies conclude that collectively, traditional land tenure systems in Africa negatively influence their adoption (Ding, 2007). Agro-technologies that require heavy initial capital and long-term or permanent land development can hardly be adopted in settings predominated by communal or inherited land tenure systems. As most of the farmlands in the study area are inherited, the overall adoption rate of SLARI-promoted grain storage technology remains low. Of course the low rate of adoption could as well be influenced by other indirect factors, such as cultivated grain type, farm size, household size and land management systems.

Cultivated crop types (e.g., vegetables) which do not require SLARIpromoted storage technologies could limit the adoption rate. It is also possible that sloping upland farms are not fertile enough to support high crop yields, in turn discouraging farmers from adopting storage technologies. Small farms/households could imply limited yield/grain production and less need for storage technologies requiring additional expenditures. Even with large farmlands, poor farm management could lead to low yield while management complexities could dissuade farmers from using some agro-technologies. Such is more the case when harvested yields are barely enough for the consumption of farming households. These and other indirect factors affect the adoption of SLARI-promoted grain storage technologies in the study area.

\section{Cultivated grain and technology adoption}

As shown in table 2, cultivated grain type is positively related to grain storage technology adoption. Lunduka et al. (2012) noted a similar association between storage technology adoption and hybrid maize varieties. The above finding suggests that farmers in the study area are more likely to cultivate hybrid grains that are suitable for preservation under the SLARI-promoted storage technologies. Off-season market prices, which are higher than harvest-season prices, could motivate farmers to adopt grain storage technologies. The very fear of higher off-season market prices could also lead even small-scale producers to use storage technologies that ensure sufficient grain availability for internal consumption during off-season periods.

\section{Other factors and technology adoption}

Based on the Logistic Regression Model analysis, farmer demographic factors (such as sex, age, marital status, farm size, farming experience, extension service access and credit access) do not significantly influence the adoption of SLARI-promoted grain storage technologies in the study area (table 2). These variables are therefore not considered to be key determinants of grain storage technology promotion and adoption in Sierra Leone. The Logistic Regression Model results contradict studies where these factors significantly influenced the adoption of agro-technologies (Paudel \& Matsuoka, 2008; Kafle, 2010).

In Sierra Leone, farm credits are often time haphazard, random, corrupt and insignificant. Farm credits are also mostly granted along political linkages or at high interest rates (Matus \& Paloma, 2014). This prevents most farmers from participating in credit operations that support improved agro-technologies. As extension agents/services are often associated with unreasonable credit loans or even extortions, small/average farmers (who make up the bulk of the farming force in Sub-Saharan Africa) try to avoid close/frequent contacts with agents they perceive as unnecessary burdens (Moiwo, 1993). Also, due to poor remuneration grids by cash-trapped ministries of agriculture across Sub-Saharan Africa, fieldlevel extension agents are mostly 
school-leavers with limited ability to sufficiently breakdown complex agrotechnologies to the level of understanding of farmers. In fact, there are cases where field-level extension workers rely on the farmers they serve for daily food and other basic amenities (Moiwo, 1993). Relationships of this nature could be responsible for the weak/non-linkages of the above factors with the promotion/adoption of agro-technologies in Sierra Leone. Hence, despite the huge repository of on/off-farm agro-technologies available today, efficient promotion methods for greater adoptions remain limited. Improvement in this direction could not only boost farmers' income, but also ensure food security for the underfed populations of the developing world.

Irrespectively, the lack of suitable storage structures or the absence of storage management technologies could force smallholder farmers to sell their farm produce immediately after harvest. This implies that these farmers generally receive low market prices for surplus produce. Efficient storage of produce, at the farm/household or collective/community level, is crucial for poverty alleviation and food/ income security. The benefit is the prosperity it could bring to smallholder farmers in Sub-Saharan Africa and the developing world at large.

\section{Conclusions and}

\section{recommendations}

This study analyzes the determinant factors of SLARI-promoted grain storage technology adoption in Sierra Leone using the Logistic Regression Model. While some factors (e.g., education and household size) significantly influence adoption, others (e. g., access to credit and extension services) little influence grain storage technology adoption in the country. With farming as the primary mode of livelihood, there is need for efficient promotion and adoption strategies of agro-produce storage technologies in Sierra Leone and the wider SubSaharan Africa.

Extension services, private/international institutions and governments should redirect more effort towards promoting post-harvest storage technologies at different (household, community and national) levels. Collective/ community storage facilities can be set up by farmer/community associations and cooperatives. Governments and non-governmental organizations (NGOs) can set up efficient storage services to be managed by trained extension agents. Also governments and NGOs could offer soft-loans/aids to trained individuals in post-harvest storage strategies to set up and run costrecovery storage facilities in rural communities. Such facilities could even be used as "warehouse receipt systems" by farmers to secure needed loans from lending institutions that require co-laterals. This could benefit not only farmers in terms of income, but also consumers in terms of food availability, supply and security.

There is also the need for participatory research that emphasizes collaboration among consumers (end users), farmers (producers), extensions agents (technology disseminators), researchers (technology developers) and decision-makers (research funders). New technologies developed as a result of such collaboration could be more suitable to local communities and acceptable by relevant stakeholders. Agro-technologies that address key concerns of consumers/farmers could further enhance food production, selfsufficiency and security at local, regional and global scales.

\section{Acknowledgements}

We thank the Harbin Institute of Technology for providing the grants for this research. We are also thankful to SLARI staff for directing the survey and data collection processes. We acknowledge the invaluable inputs of the anonymous reviewers and editors by way of insightful comments and suggestions during review of the manuscript.

\section{References}

Agwu AE, Ekwueme JN, Anyanwu AC, 2008. Adoption of improved agricultural technologies disseminated via radio farmer programme by farmers in Enugu State, Nigeria. African Journal of Biotechnology 7(9):1277-86.

Alavalapati JRR, Luckert MK, Gill DS, 1995. Adoption of agro forestry practices: A case study from Andhra Pradesh. Indian Journal of Agroforestry Systems 32(1):1-14.

APHLIS (African Postharvest Losses Information System), 2011. An innovative framework to analyse and compute quantitative Postharvest losses for cereals under different farming and environmental conditions in East and Southern Africa. http://publications.jrc.ec.europa.eu/repository/ bitstream/111111111/15877/1/lbna24712enc.pdf

Basorun JO, Fasakin JO, 2012. Factors influencing rice production in Igbemo-Ekiti Region of Nigeria. Journal of Agriculture, Food \& Environmental Science 5(1):1-9.

Chandola M, Rathore S, Kumar B, 2011. Indigenous pest management practices prevalent among hill farmers of Uttarakhand. Indian Journal of Traditional Knowledge 10(2):311-5.

Condous G, Okaro E, Khalid A, Zhou Y, Lu C, et al., 2004. The use of a new logistic regression model for predicting the outcome of pregnancies of unknown location. Oxford Journal Medicine \& Human Reproduction 19(8):1900-10.

Davis K, 2008. Intersectional as buzzword. A sociology of science perspective on what makes a feminist theory successful. Journal of Feminine Theory 9:167-85.

Ding C, 2007. Policy and praxis of land acquisition in China. Land Use Policy 24(1):1-13.

Deressa TT, Hassan RM, Ringler C, Alemu T, Yesuf $M$, 2009. Determinants of farmers' choice of adaptation methods to climate change in the Nile Basin of Ethiopia. Global Environmental Change 19:248-55.

Ellis $\mathrm{RH}$, Hong TD, 2007. Seed longevity moisture content relationships in hermetic and open storage. Journal of International Seed Testing Association 35(2):423-31.

FAO (Food and Agriculture Organization of the United Nations), 2011. Global food losses and food waste: Extent, causes and prevention; 2011. http:// www.fao.org/docrep/014/mb060e/mb060e00.pdf

Francis C, Lieblein G, Gliessman S, Breland TA, Creamer N, et al., 2003. Agro-ecology: The ecology of food systems. Journal of Sustainable Agriculture 22(3): 99-118.

Goldman A, 1991. Tradition and change in post harvest pest management in Kenya. Agriculture \& Human Values 8(1-2):99-113.

Guha S, Leonard J, 2002. Motivation in elementary mathematics: How students and teachers benefit from computers. Journal of Human Social Science \& Law 46(1):40-3.

Heritz RS, 2004. Realizing the promise and potential of African agriculture. A proceeding in a Food Security Council meeting held at the InterAcademy Council in Amsterdam. InterAcademy Council.

Hosmer DW, Lemeshow S, 2000. Applied logistic regression, 2nd ed. Wiley \& Sons, 2000.

Howell DC, 2010. Statistical methods for psychology, 7th ed. Belmont (USA): Thomson Wadsworth.

Ibekwe UC, Eze CC, Onyemauwa CS, Henri-Ukoha A, Korie OC, et al., 2010. Determinants of farm and off-farm income among farm households in South East Nigeria. Academic Arena 2(11):11-4.

Kafle B, 2010. Determinants of adoption of improved maize varieties in developing countries. A review. International Research Journal of Applied Basic Sciences 1(1):1-7. 
Karki LB, Bauer S, 2004. Technology adoption and household food security. Analyzing factors determining technology adoption and impact of project intervention: $A$ case of smallholder peasants in Nepal. http://www.tropentag.de/2004/abstracts/ full/107.pdf

Kleijnen M, de Ruyter K, Wetzels M, 2004. Consumer adoption of wireless services: Discovering the rules, while playing the game. Journal of Interactive Marketing 18(2):51-61.

Lleras-Muney A, 2005. The relationships between education and adult mortality in the United States. Review of Economic Studies 72(250):189-221.

Lunduka R, Fisher M, Snapp S, 2012. Could farmer interest in a diversity of seed attributes to explain adoption plateaus for modern maize varieties in Malawi? Journal of Food Policy 37(5):504-10.

Maconachie R, Hilson G, 2011. Artisanal gold mining: A new frontier in post- conflict Sierra Leone? Journal of Development Studies 47 (4):595-616.

Matus SSL, Paloma SG, 2014. Farm viability of (semi)subsistence smallholders in Sierra Leone. African Journal of Agricultural \& Resource Economics 9(3):165-82.

Menard SW, 2002. Applied Logistic Regression, 2nd ed.Thousand Oaks (USA): SAGE Publications.

Moiwo JP, 1993. Job satisfaction of village-level extension workers (VEW) in Sierra Leone - A case study of the northern and southern provinces of Sierra Leone. BSc. Thesis Report.
Navin CP, 2001. Lined bulk bag. US Patent 6, 205, 845 B1. http://www. freepatentsonline.com/ 6305845.pdf

Neupane RP, Sharma KR, Thapa GB, 2002. Adoption of agroforestry in the hills of Nepal: A logistic regression analysis. Agricultural Systems 72(3):177-96

Odeyemi OO, Ashamo MO, Akinkurolere RO, Olatunji AA, 2010. Resistance of strains of rice weevil, Sitophilus Oryzae (Coleoptera: Curculionidae) to pirimiphos methyl. 10th international working conference on stored product protection. Akure, Ondo State, Nigeria.

Parfitt J, Barthel M, Macnaughton S, 2010. Food waste within food supply chains: Quantification and potential for change to 2050. Philosophical Transactions of the Royal Society. Biological Sciences $365: 3065-81$.

Paudel P, Matsuoka A, 2008. Factors influencing of improved maize varieties in Nepal: A case study of Chitwan district. Australian Journal of Basic \& Applied Sciences 2(4):823-34.

Pinstrup-Andersen P, 2009. Food security: Definition and measurement. Journal Biomedicine \& Life Sciences 1(1):5-7.

Soule MJ, Tegene A, Wiebe KD, 2000. Land tenure and the adoption of conservation practices. American Journal of Agricultural Economics 82(4):9931005.

Tan KS, Chong SC, Lin B, Eze UC, 2009. Internetbased ICT adoption: Evidence from Malaysian SMEs. Industrial Management \& Data Systems 109(2):224-44.
Tester M, Langridge P, 2010. Breeding technolo gies to increase crop production in a changing world. Science 327(5967):818-22.

Toenniessen G, Adesina A, DeVries J, 2008. Building an alliance for a green revolution in Africa. Annals of New York Academy of Science 1136:233-42.

Tourenq C, Aulagnier S, Durieux L, Lek S, Mesléard $\mathrm{F}$, et al., 2001. Identifying rice fields at risk from damage by the greater flamingo. Journal of Applied Ecology 38:170-9.

USDA (United States Department of Agriculture) 2000. A millennium free from hunger. US national progress report on implementation of the us action plan on Food Security and World Food Summit.

Vallier A, Vincent-Monegat C, Laurenencon A Heddi A, 2009. RNA in the cereal weevil Sitophilus spp: Systemic gene knockdown in the bacteriome tissue. BMC Biotechnology 9:44. doi: 10.1186 1472-6750-9-44

WB/FAO (World Bank/Food and Agriculture Organization of the United Nations), 2011. Missing food: The causes of postharvest grain losses in Sub-Saharan Africa. Report No. 60371-AFR http:/ siteresources. worldbank.org/INTARD/Resources/ MissingFoods 10_web.pdf

Wetengere K, 2010. Determinants of adoption of a recommended package of fish farming technology: The case of selected villages in Eastern Tanzania. Advanced Journal of Food Science \& Technology 2 (1):55-62. 